\title{
Pedagogical impact of internal training applied to the Academic League of Internal and Surgical Medicine
}

\author{
Impacto Pedagógico das Capacitações Internas Aplicadas \\ na Liga Acadêmica de Medicina Interna e Cirúrgica
}

\section{João Henrique Fonseca do Nascimento ${ }^{1}$ (C) Selton Cavalcante Tomaz ${ }^{2}$ (1) Alan Rodrigues de Azevedo 3 (1) André Gusmão Cunha ${ }^{4}$ (i) André Bouzas de Andrade 5 (1)}

\footnotetext{
${ }^{1}$ Autor para correspondência. Universidade do Estado da Bahia (Salvador). Bahia, Brasil. joao.fonseca@live.com 2-5Universidade do Estado da Bahia (Salvador). Bahia, Brasil. seltontomaz@gmail.com, alanazvdo@yahoo.com.br, agcunha@uneb.br, abandrade@uneb.br
}

\begin{abstract}
INTRODUCTION: Academic Leagues of Medicine are extracurricular activities, which recognize the student's protagonism in knowledge's production, such as training and teaching-learning experiences developed by students. OBJECTIVE: To assess the training's efficiency in surgical technique applied at the Academic League of Internal and Surgical Medicine (LAMIC). METHODS AND MATERIALS: We evaluated the effect of the LAMIC's training promoted to its associated students, comparing them to a non-exposed group. A questionnaire was used as an evaluation tool. It contained 20 objective questions and all students had up to 30 minutes to answer it. The $60 \%$ mark of correct answers was set as a threshold for considering proficient knowledge. For statistical analyses, Mann-Whiney $U$ test and Fisher's exact test were performed, adopting $p<0.01$ as significant. RESULTS: Sixty-nine students composed the sample population, whom 24 LAMIC-students were exposed to internal training and 45 nonexposed students. Among LAMIC-students, 91.7\% had supraliminal results, while only $2.2 \%$ of non-exposed students reached this mark $(p<0.01$; odds ratio, $O R=354.8)$. There was statistically significant association between LAMIC-students' results and good performance in: fundamentals in surgery $(p<0.01, O R=5.0)$, surgical risk assessment $(p<0.01, O R=3.4)$, patient $(p<0.01, O R=183.5)$ and surgical team $(p<0.01, O R=9.6)$ positioning, surgical center $(p<0.01, O R=84.0)$, and instrumentation $(p<0.01, O R=125.3)$. CONCLUSION: Participation in internal training promoted by the academic league fostered better results in surgical knowledge, corroborating the concept that student's leadership in teaching experiences may contribute to a better learning experience and medical formation.
\end{abstract}

KEYWORDS: Teaching. Education Medical. Students Medical.
RESUMO | INTRODUÇÃo: Ligas Acadêmicas (LA) de Medicina são atividades extracurriculares, as quais reconhecem o protagonismo do aluno na produção do conhecimento, como as capacitações internas desenvolvidas por estudantes. OBJETIVO: Avaliar a eficácia das capacitações internas em técnica operatória aplicadas na Liga Acadêmica de Medicina Interna e Cirúrgica (LAMIC-LT) aos seus ligantes. MÉTODOS: Avaliamos os resultados das capacitações internas da LAMIC-LT aplicadas aos alunos-ligantes, comparando-os com estudantes não-expostos. Utilizou-se um questionário como instrumento de avaliação contendo 20 questões objetivas, cujos participantes tiveram até 30 minutos para respondê-lo. A pontuação de $60 \%$ de respostas certas foi adotada como um limite mínimo para considerar o conhecimento sedimentado. Para análises estatísticas, foram aplicados o teste Mann-Whitney $U$ e teste exato de Fisher duplo caudado, considerando $p<0,01$ significante. RESULTADOS: 69 estudantes compuseram a amostra, dos quais 24 foram estudantes LAMIC, expostos aos treinamentos internos e 45 estudantes regulares não-expostos. Entre os expostos, 91,7\% apresentaram resultados supralimiares, enquanto apenas $2,2 \%$ dos estudantes não-expostos atingiram essa marca ( $p<0,01$; odds ratio, $O R=354,8$ ). Houve correlação entre os resultados dos estudantes-LAMIC e bom desempenho em: fundamentos em cirurgia $(p<0,01, O R=5,0)$, avaliação de risco cirúrgico $(p<0,01$, $O R=3,4)$, posicionamento do paciente $(p<0,01, O R=183,5)$ e da equipe $c i-$ rúrgica ( $p<0,01, O R=9,6)$, centro cirúrgico $(p<0,01, O R=84,0)$ e instrumentação ( $p<0,01, O R=125,3)$. CONCLUSÃo: A participação nas capacitações internas promovidas pela liga acadêmica possibilitou melhores resultados em conhecimento cirúrgico, corroborando com o conceito de que lideranças estudantis na experiência de ensino podem contribuir para uma melhor aprendizagem e formação médica.

PALAVRAS-CHAVE: Ensino. Educação Médica. Estudantes de Medicina. 


\section{Introduction}

Since the beginning of the 21st century, the most important national institutions of tertiary education have been strenuously debating one of the most current concerns - medical formation in Brazil.1.2 It is recognized that medical formation has been undergoing intensechanges, which recent demands go beyond classrooms and textbooks. ${ }^{1}$ The applicability of new and innovatory pedagogical tools has been tried as a way for complementing the formation of health professionals, even at the undergraduate level. ${ }^{2,3}$ On this basis, academic leagues have gained more and more space in life sciences courses, particularly in schools of medicine. ${ }^{1,2,4}$

The academic leagues ( $A L)$ in medicine are mainly student entities, which are headed by a group of students dedicated to a deepening in general and specific medical themes. ${ }^{4}$ Undoubtedly, the ALs are a current reality in most of the universities across the country. ${ }^{4,5}$ As a group of undergraduate students united by a common scientific interest, the ALs intend to create a prosperous and stimulating environment, which, in a free and democratic manner, disposes of organized educational strategies to learn, in the so-called "parallel curriculum". .6 This, in turn, aims to substantiate learning skills, leadership profiles, competence and capabilities for an expanded professional formation. 5,6 Besides, it encompasses active, interactive, and reflective pedagogical methodologies that emphasize the autonomy of the academic student and engage the three educational pillars of the Brazilian universities - the interface of teaching, research, and extension for undergraduate courses. 3,4, .

In addition, the ALs allow a multidisciplinary view of medical practice for the undergraduate, as well as the notion of integrative care, active knowledge search, experience in planning academic activities, and finally, promotes an extended, critical, and ethical graduation. $., 6,0,8$ These advantages, made possible by the ALs, are in line with the National Curricular Guidelines for the Undergraduate Courses of Medicine ${ }^{7}$, since this guideline considers that the student is also responsible for its own learning process, highlighting the need for intellectual autonomy, while committing itself to the formation of the future health professionals generation. ${ }^{4 . Z}$ These fundamentals underline the encouragement of academic and professional mobility, promotion of critical thinking, and production of new scientific knowledge and methods., In this strong commitment, the Academic League of Internal and Surgical Medicine - Trauma League (Liga Acadêmica de Medicina Interna e Cirúrgica - Liga do Trauma, LAMIC or LAMIC-LT), at the Bahia State University (Universidade do Estado da Bahia, UNEB), was founded in 2016.

In parallel, Surgery is an essential field of medical formation, and it is a wide interest by the students of the course. Surgery, as a professional practice, is responsible for the treatment of diseases through manual procedures and, as a scientific subject, is a branch of medicine that involves surgical pathology, clinical and therapeutic particular knowledges., .10 The Operative Technique and Experimental Surgery (Técnica Operatória e Cirurgia Experimental, TOCE), an academic subject commonly offered during the second year of the medical course of most universities in Brazil, is one of the thematic pillars commonly addressed in ALS, especially those aimed at studying the fundamentals of the surgical field. From a basic perspective, the TOCE is divided into studying surgical field basic concepts, the instruments and their handling, and the general manipulation of tissues.. .10 On the other hand, there is a specialized perspective comprising sets of specific maneuvers and techniques, which each of them is responsible for performing operative treatments on specific disorders, anatomical regions, or organs., 2,10

In this process of discovering and applying teachinglearning new methodologies, some instruments are still considered as good evaluation tools for such objectives. ${ }^{11,12}$ Authors in pedagogical sciences reaffirm that the evaluation process has been discussed and rethought by theorists concerned with proposing strategies that promote a better understanding of learning experiences. 11 The assessment of learning can be based on several instruments, and the written test is particularly relevant, which, although not ideal for assessing practical skills, is a valid instrument to evaluate the acquisition of knowledge.1112 Quinquer and colleagues demonstrate that the use of tests as an evaluation tool gives a greater scientific, objective, and quantifiable feature for teaching processes, with the potential of regulating and measuring learning, following this intentionality. ${ }^{13}$

Therefore, given the significance of the theme and the scarcity of studies related to academic leagues in the medical scientific literature, the present study aimed 
to evaluate, in the form of written test assessment, the effect of internal training in academic leagues, related to TOCE, as a pedagogical tool and its impacts on teaching-learning surgery experience, applied in the Academic League of Internal and Surgical Medicine, at the Bahia State University, Brazil.

\section{Methods}

\section{Study design, ethics and participants}

This cross-sectional study was conducted in 2018 by the Academic League of Internal and Surgical Medicine, at the Bahia State University (UNEB), and students in the second year of medicine were enrolled. LAMIC-student members that attended the internal training in TOCE were included and classified as "the exposed" group, and non-LAMIC regular medical students of the second year that did not attend those training were included in "the non-exposed" group (control group). Both groups of undergraduate students (exposed and nonexposed) were in the second year of medical school and enrolled in the regular academic subject of TOCE of the respective year. LAMIC-members that did not attend the internal training and LAMIC/nonLAMIC students who did not wish to participate were excluded. The project was previously approved by the university's Ethical Committee and the Brazil Platform (Plataforma Brasil) of the Ministry of Health (Registration number in the Research Ethics Committee: 2.669.895 and CAAE number: 86404418.2.0000.0057, dated May 23, 2018).

\section{The internal training and instrument}

LAMIC's Student Directorate set the internal training in the calendar of activities of the league, and the teaching interventions were performed by the president of LAMIC (the student-lecturer), previously instructed and trained by LAMIC's professor advisors. However, it is important to emphasize that, despite the relevant role of the professors, the training itself was organized and executed by the undergraduate students, members of this academic league - LAMIC.
The meetings took place in an extra round of activities outside the academic routine. Datashow projector was used to expose the classes on PowerPoint slides, based on the consecrated textbooks in surgical formation, recommended by the professors of surgery, faculty members of UNEB's Department of Life Sciences. The syllabus explored was: i. Concepts in Surgery; ii. Assessment and Recognition of Risks in Surgery; iii. Surgical Management and Skills; iv. Surgical Classifications; v. Operating Room; vi. Surgical Terminology; vii. Patient Positioning; viii. Surgical Team Positioning; ix. Asepsis and Antisepsis; $x$. Surgical Instruments and Instrumentation. To classify a subject as an "exposed individual", this student must have attended the pedagogical intervention, fostered as the LAMIC's internal training - a twoday course with 5 hours/day per semester, in which, among several themes in the syllabus, a single twohour lecture was dedicated to TOCE and this lecture and its effects were the selected object of this study.

A questionnaire-test was used as an evaluation instrument of the learning moment, and it was composed of 20 multiple-choice questions, selected by the professor advisor of the group. To prevent or minimize bias, only the professor advisor and the student-lecturer knew about the existence of the test before the execution of the training. With this, it was expected to avoid extraordinary efforts by the students while attending the training, for instance paying extra-attention to the classes to reach better results on the test. Thus, all LAMIC-students attended the classes as a regular routine training. The moment taken to apply the instrument was a minimum of 1 hour after the end of the training, up to a maximum of 7 days after, once 7 days would set the moment for the next LAMIC regular meeting. The same instrument was applied to non-LAMIC regular medical students of the second year, aiming to gather data of the nonexposed control group.

As a discriminatory cut-off, the mark of $60 \%$ of correct answers was defined as a threshold to assume proficient knowledge by the subject and to be considered a positive knowledge acquisition. All of the students, before enrolled in the research, declared acceptance, and signed the informed consent form, according to the norms and ethical recommendations for scientific research. 


\section{Statistical analysis}

The normality of the variables was assessed by the Shapiro-Wilk test. Descriptive statistics such as mean \pm standard deviation (SD), median, interquartile range (IQR: Q1 - Q3), besides odds ratio (OR) and confidence intervals (CI), were used to describe number and proportion of correct answers.

For the statistical analysis, Mann-Whitney $U$ test and Fisher's exact test were used to compare differences between groups, considering $\mathrm{p}<0.01$ significant. The data management and computation were conducted using the public domain program R version 3.3.2 (The R Foundation for Statistical Computing, Vienna, Austria, http://www.r-project. org) and the VassarStats: Website for Statistical Computation (http://vassarstats.net/ - University of Chicago).

\section{Results}

The 69 subjects included in this study were enrolled in the second year of medicine, in which 24 students were LAMIC-members exposed to the internal training and 45 students, non-LAMIC members not exposed. The internal training occurred twice, by the end of the first and second semester of 2018, and they had an average duration of 1.5 hours each. The application of the instrument had a maximum duration of 30 minutes.

LAMIC-students reached a mean score of $77.7 \% \pm 0.11$ of correct answers, and it was higher than the mean score achieved by students not exposed to internal training $(31.6 \% \pm 0.11)$ (Figure 1). Also, there was a statistically significant difference between the results of LAMIC-students (median of 0.80) compared to the control group (median of 0.30) (Mann-Whitney $U=1077.00 ; p<0.01$ ) (Table 1).

Figure 1. Results of the general performance means of LAMIC-students and regular (non-LAMIC) students submitted to the evaluative instrument

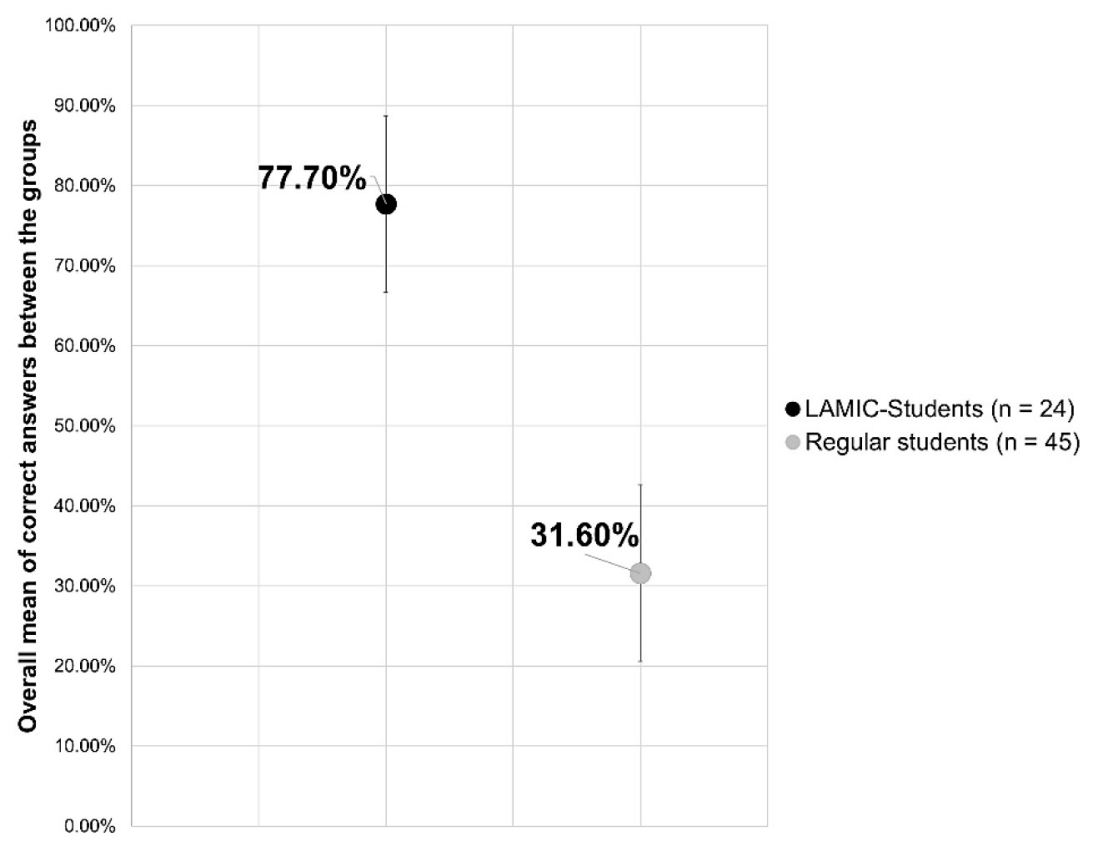

Moreover, 22 LAMIC-member (91.7\%) exceeded the cut-off of $60 \%$ of correct answers, while only a single nonLAMIC regular student (2.2\%) reached this score ( $p<0.01$; odds ratio, OR $=354.8$ [43.3-10160]). 
Table 1. General and discriminated by theme results

\begin{tabular}{|c|c|c|c|c|c|c|c|c|c|}
\hline & \multicolumn{4}{|c|}{ LAMIC-STUDENTS ( $\mathrm{N}=\mathbf{2 4})$} & \multicolumn{4}{|c|}{ CONTROL $(\mathrm{N}=45)$} & \multirow[b]{2}{*}{$\begin{array}{c}p- \\
\text { value }\end{array}$} \\
\hline & MEAN & SD & MEDIAN & $\begin{array}{c}\text { IQR } \\
\text { (Q1 - Q3) }\end{array}$ & MEAN & SD & MEDIAN & $\begin{array}{c}\text { IQR } \\
\text { (Q1 - Q3) }\end{array}$ & \\
\hline Overall result & 0.777 & 0.11 & 0.800 & $0.74-0.85$ & 0.316 & 0.11 & 0.300 & $0.25-0.4$ & $<0,01$ \\
\hline \multicolumn{10}{|l|}{ THEMES } \\
\hline $\begin{array}{l}\text { Concepts in Surgery } \\
\text { Surgical Risk }\end{array}$ & 0.583 & 0.26 & 0.666 & $0.33-0.67$ & 0.303 & 0.27 & 0.333 & $0.0-0.33$ & $<0,01$ \\
\hline Assessment & 0.729 & 0.29 & 0.750 & $0.5-1.0$ & 0.378 & 0.40 & 0.500 & $0.0-0.50$ & $<0,01$ \\
\hline Surgical Conduct & 0.861 & 0.13 & 0.750 & $0.75-1.0$ & 0.444 & 0.21 & 0.500 & $0.25-0.50$ & $<0,01$ \\
\hline $\begin{array}{l}\text { Patient Positioning } \\
\text { Surgical Team }\end{array}$ & 0.802 & 0.21 & 0.750 & $0.75-1.0$ & 0.178 & 0.21 & 0.000 & $0.0-0.25$ & $<0,01$ \\
\hline Positioning & 0.791 & 0.19 & 0.666 & $0.67-1.0$ & 0.274 & 0.25 & 0.333 & $0.0-0.33$ & $<0,01$ \\
\hline Surgical Center & 0.625 & 0.37 & 0.500 & $0.5-1.0$ & 0.400 & 0.27 & 0.500 & $0.0-0.50$ & $<0,01$ \\
\hline Instrumentation & 0.865 & 0.18 & 1.000 & $0.75-1.0$ & 0.250 & 0.23 & 0.250 & $0.0-0.25$ & $<0,01$ \\
\hline
\end{tabular}

SD: standard deviation; IQR: interquartile range

We also analyzed the results divided by 7 thematic axes in surgical education, related to Concepts in Surgery, Surgical Risk, Surgical Conduct, Patient Positioning, Team Positioning, Surgical Center and Instrumentation.

LAMIC-students results, exposed to internal training, were notably above average in Instrumentation $(86.5 \% \pm$ 0.18; median of 1.000), Surgical Conduct ( $86.1 \% \pm 0.13$; median of 0.750$)$, Patient Positioning ( $80.2 \% \pm 0.20$; median of 0.750), Surgical Risk (72.9\% \pm 0.29 ; median of 0.750) and Surgical Center (79.1\% \pm 0.19 ; median of 0.500), and each of these results was statistically significant when compared to the non-exposed group (Mann-Whitney $U$ $=1043.00, p<0.01$; Mann-Whitney $U=1012.50, p<0.01$; Mann-Whitney $U=1044.50, p<0.01$; Mann-Whitney $U$ $=$ 798.50, $p<0.01$; Mann-Whitney $U=1003.00, p<0.01$; respectively) (Table 1 and Figure 2). In closer analyses, although LAMIC-students reached lower scores in Team Positioning (62.5\% \pm 0.36 , median of 0.666) and Concepts in Surgery $(58.3 \% \pm 0.26$, median of 0.666 ), those scores were still statistically different (Mann-Whitney $\mathrm{U}=729.00$, $\mathrm{p}<0.01$; Mann-Whitney $\mathrm{U}=819.00, \mathrm{p}<0.01$; respectively) than those reached by non-exposed regular students $(40 \% \pm 0.27$; median of $0.333 ; 30.3 \% \pm 0.27$, median of 0.333 ; respectively) (Table 1 and Figure 2$)$.

Figure 2. Comparative results of the seven thematic axes addressed in the evaluation instrument between LAMIC-students and non-LAMIC students

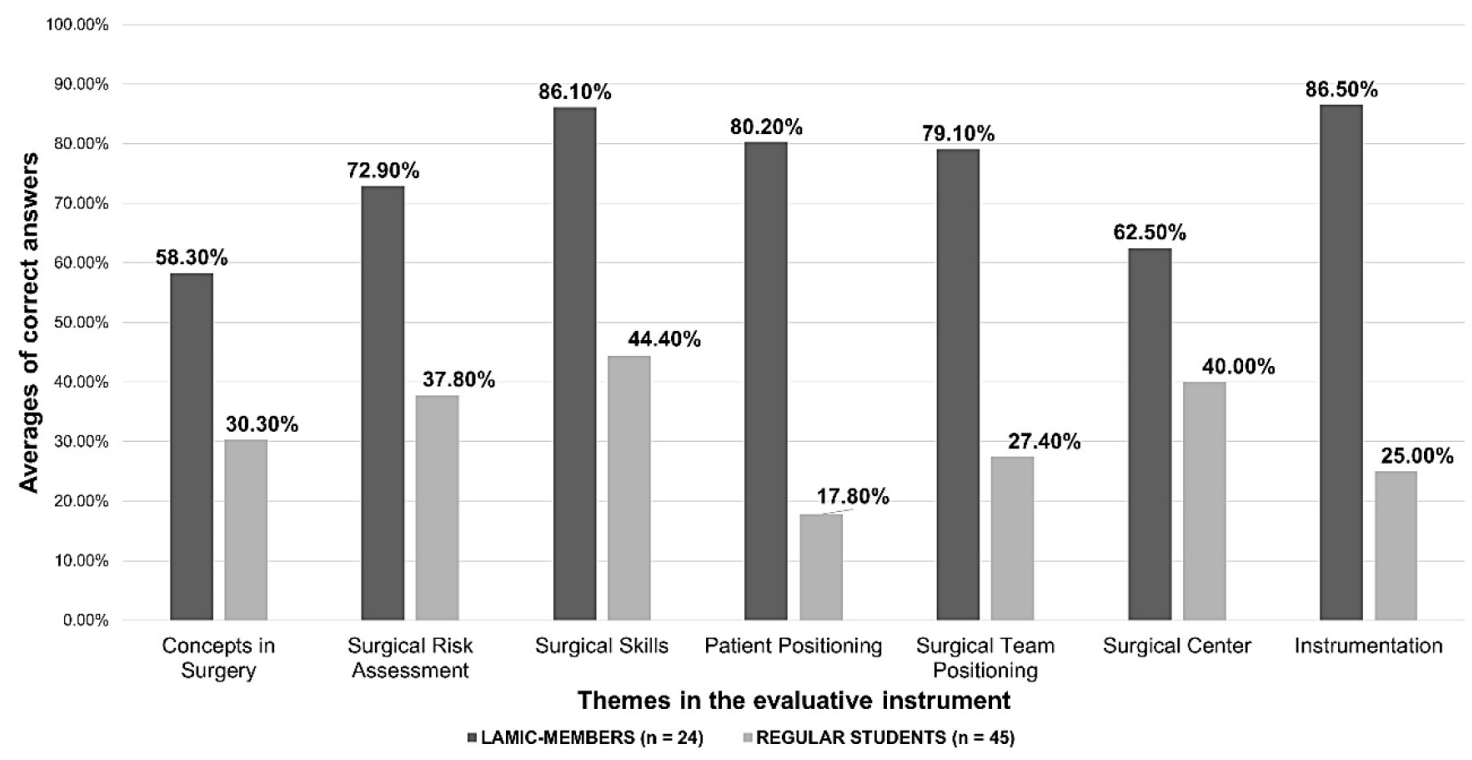


Discussion

This study aimed to investigate if academic leagues, such as LAMIC-LT, could positively influence surgical education with new pedagogical approaches for the undergraduate student. These independent student groups, such as the LAMIC-LT, provide theoretical moments alternating with practical activities. ${ }^{5}$ Additionally, the internal training envisions the development, progression, structuring, and systematization of scientific activities in the routine of an academic league. Intending to bring the knowledge of the group to the same level, the internal training allows them to search information, to substantiate data, and to debate their acquisitions autonomously, generating a vast ground of medical skills, always through scientific articles, certified textbooks, and instructed by the professor advisor of the group. It also enables them to stimulate scientific curiosity focusing on the key themes adopted by the team, reinforcing the intentionality of the protagonism of the student in a creative and fruitful scenario of teaching-learning interchange..$^{8}$

Our results showed that better learning performance was associated to the members of Academic League of Internal and Surgical Medicine - Trauma League, who engaged in Operative Technique and Experimental Surgery's internal training. The results of LAMIC-students evince a statistically higher chance of reaching percentages above the $60 \%$-correct answers mark, which, for our instrument of evaluation, we recognized as a percentage that represents a meaningful gain in surgical learning theoretical skills $(p<0.01 ;$ OR $=359.8$ [43.3 - 10160]). As a requisite, LAMIC adopts and promotes internal training for new members at the beginning and the end of each semester, regularly - intending to level these new LAMIC-members with veterans LAMICpartners. Parallel to this, once the veteran members are also invited to attend the internal training, they can review already seen concepts and improve their learning abilities, obtained in previous exposures. The objective of this achievement is always to guarantee the teaching, research, and extension activities excellence carried out by this medical league. Since the tests applied to veteran members could generate confusing data, the scores achieved by those members who were previously exposed to past training were not included in the analyzes.
Conjointly, it is important to understand that this is a pioneering study among most of the researches related to academic groups and there is no previous study that statistically compared the influences in knowledge acquisition of ALs' internal training across members and non-members of academic leagues of medicine in Brazil until the present moment. We sought to evaluate quantitatively and statistically the pedagogical impact in undergraduate education induced and provoked by these student organizations. Ramalho and colleagues demonstrated that the influence and repercussion of the academic league in medical education denote a notorious increase in cognitive commitment and performance of the student, also with a direct effect on the proportion of how much this student is involved in learning activities and being the active agent of teaching. ${ }^{14}$ From that theoretical postulate, it is recognized that having LAMIC-students as the organizers, coordinators, and executors of the internal training may enhance the benefits of it, once these students, by elaborating the didactic procedures, also contributed to the improvement of their own graduating process, in a reflexive teaching-learning perspective.

In this same analysis, it is increasingly important to discuss new methodologies in academic fields, as proposed in our evaluative study by highlighting the student as an agent of the construction, elaboration and organization of its own learning process. These active teaching methodologies are part of a new paradigm of student-centered learning, which has been strongly emphasized by the new National Curriculum Guidelines of Graduation Course in Medicine, elaborated by the Brazilian Ministry of Education, reinforcing the importance of active methods of teaching for professional formation in the new century. ${ }^{?}$ It is clear in this guideline, the relevance of designing activities that allow students to acquire knowledge through active, reflexive, and interactive methodologies - a factor that can be presented as a secondary outcome result of the present investigation - rather than only submit the student to the passive acquisition of information, exhibited and conducted by teachers and professors. ${ }^{2.14}$ It is important to recognize that our experience with the internal training on TOCE is a single contribution from all the possibilities of teaching-learning practices associated with the AL and fostered by LAMIC, such as simulated clinics and OSCE, black-box training in laparoscopic 
simulation, Simulated Patient Instructors (SPI), problem-based learning, among others, and this is the main difference between the active methodological approaches offered by academic leagues and the current traditional methodologies adopted by most teachers in Brazilian universities.

The literature demonstrates that an integrated model of motivation, learning strategies, and active student participation arefundamental to new forms of teaching in medical school, and that unfolds in an effective acquisition of cognitive performance and academic self-esteem. This topic on pedagogical development relies on an anthropological constructivist practice, which, in the model adopted by LAMIC, promotes scientific autonomy and self-management of the student learning process. $., 6,6,15$

The present investigation had some limitations that need to be brought to discussion. One relevant limitation to our study included its design, a crosssectional study, whose nature did not allow us to perform a test-retest method of assessment, however, this did not invalidate the positive role of $A L$ in the learning process, in leadership, and in developing self-responsibility. Moreover, it is important to underline that, despite the low performance of the non-exposed students, they were still in the two first years of medical school, years that promotes little contact with surgery and surgical learning, and this may be a factor of interference in our analyses. In an attempt to minimize this bias, we adopted a threshold value of $60 \%$ of correct answers, but we reaffirm that studies with the traditional $70 \%$ mark are necessary to complement our results. Furthermore, the present study compared students enrolled in an academic league that has the teaching of surgery as an important structural focus, leading to the assumption that these students have a stronger interest in surgery than the general student population. Organizing a control group composed of non-LAMIC students who share the same strong interest in surgery may represent a relevant research strategy to substantiate the results. Apart from that, the sample population was composed of students - LAMIC and non-LAMIC - from the same university, which stimulates future comparison with subjects from other university centers, in the same academic semesters and the same city (Salvador). In a complementary plan, the comparison with individuals from other Brazilian university centers, such as São Paulo, Rio de Janeiro, and Belo Horizonte, could provide more data that can assist in understanding the specific inferences, correlated with our findings.

Beyond the importance of promoting knowledge gain, as evidenced by higher mean grades achieved by LAMIC-members, analyses on the theme demonstrate other benefits of these activities. Some of the benefits can be cited as stimulating the development of dynamics strategies for instructional exchange, teaching and research new methods, supplementation of extracurricular activities, wellbeing feeling of the academic student, professional improvement, and greater contact with the university experience, already highlighted by several authors as an extremely positive factor for the learner in a tertiary course of medicine. ${ }^{1,3-6,14}$

\section{Conclusion}

The academic leagues of medicine, such as the Academic League of Internal and Surgical Medicine, are unquestionable university phenomena within the prism of Brazilian university education, which erupted at the beginning of the early 2000s. The outcomes fostered by these groups within the teaching-learning process were positive, and despite the intrinsic limitations of a cross-sectional study, the findings of the present analytical study showed that the internal training represented a singular opportunity for developing teaching-learning activities and skills, innovative methodologies direct related surgical education, scientific research, and also collaborate with the professional formation of its members. Finally, it is meaningful to assert the need to improve essential aspects of medical education and, in a statistically effective way, it could be observed that the internal training, evaluated in this paper, were an effective pedagogical mechanism, made possible by the $A L$, evincing the beneficial role for the advancement of surgical didactic provided by this type of organization. 


\section{Acknowledgments}

The authors thank all the members and colleagues of the Academic League of Internal and Surgical Medicine (Liga Acadêmica de Medicina Interna e Cirúrgica - LAMIC), its advisors, and, especially, Professor Alan Rodrigues Azevedo for being always supportive and the first LAMIC's mentor at its very beginning.

\section{Authors' contribution}

Nascimento JHF, Tomaz SC, Azevedo AR, Cunha AG, Andrade AB participated in the conception, design, analysis, data interpretation and final approval of the manuscript. Nascimento JHF, Tomaz SC and Andrade $A B$ participated in data collection and assembly. Nascimento JHF, Tomaz SC, Andrade AB participated in the writing of the manuscript. Nascimento JHF, Cunha AG and Andrade $A B$ participated in the review of the language of the article.

\section{Competing interests}

No financial, legal or political competing interests with third parties (government, commercial, private foundation, etc.) were disclosed for any aspect of the submitted work (including but not limited to grants, data monitoring board, study design, manuscript preparation, statistical analysis, etc.).

\section{References}

1. Belfor JA, Sena IS, Silva DKBD, Lopes BRS, Koga Júnior M, Santos BEF. Faculty teaching skills perceived by medical students of a university of the Brazilian Amazon region. Cien saude colet. 2018;23(1):73-82. https://doi.org/10.1590/1413$\underline{81232018231.21342017}$

2. Aparicio F, Morales-Botello ML, Rubio M, Hernando A, Muñoz $\mathrm{R}$, López-Fernandez, et al. Perceptions of the use of intelligent information access systems in university level active learning activities among teachers of biomedical subjects. Int J Med Inform. 2018;112:21-33. https://doi.org/10.1016/j.ijmedinf.2017.12.016

3. Gal B, Rubio M, Iglesias E, González P. Evaluation of participatory teaching methods in undergraduate medical students' learning along the first academic courses. PLoS One. 2018;13(1):e0190173. https://doi.org/10.1371/journal.pone.0190173

4. Hanamoto Filho PT, Venditti VC, Oliveira CC, Vicentini HC, Schellini SA. Medical academic leagues: extending medical science to society. Rev Ciência em Extensão [Internet]. 2011;7(1):126. Available from: http://ojs.unesp.br/index.php/revista_proex/ article/view/366/406
5. Pêgo-Fernandes PM, Mariani AW. O ensino médico além da graduação: ligas acadêmicas. Diagn Tratamento [Internet]. 2011;16(2):50-1. Available from: http://files.bvs.br/ upload/S/1413-9979/2011/v16n2/a2048.pdf

6. Hornero ZM. Ligas Acadêmicas de Medicina na UNIFESP: papel na formação do graduando e importância da busca ativa de informação científica [thesis] [Internet]. São Paulo: Universidade Federal de São Paulo; 2015. Available from: http://www2.unifesp. br/centros/cedess/producao/teses/tese 179 zuleika hornero.pdf

7. Resolução CNE/CES No 4, de 7 de Novembro de 2001 (Brasil). Institui Diretrizes Curriculares Nacionais do Curso de Graduação em Medicina. [Internet]. Diário Oficial da União. 2001 nov 9. Available from: http://portal.mec.gov.br/cne/arquivos/pdf/CESO4. pdf

8. Milanesi ACB, Rezende RQ, Lovato BH, Vieira Bellettini $C$, Sukiennik R. Evaluation of interactions between students on learning process in Pediatrics. Boletim Científico de Pediatria [Intetnet]. 2013:2(3):89-94. Available from: http://www.sprs.com. br/sprs2013/bancoimg/140324183338bcped 1303 05.pdf

9. Goffi FS. Técnica cirúrgica : bases anatômicas, fisiopatológicas e técnicas da cirurgia. São Paulo: Atheneu; 2004.

10. Marques RG. Técnica operatória e cirurgia experimental. Rio de Janeiro: Guanabara Koogan; 2005.

11. Moraes DAF. Prova: instrumento avaliativo a serviço da regulação do ensino e da aprendizagem. Est Aval Educ. 2011;22(49):233-58. https://doi.org/10.18222/eae224920111975

12. Nuhs AC, Tomio D. A prova escrita como instrumento de avaliação da aprendizagem do aluno de Ciências. Est Aval Educ [Internet]. 2011;22(49):259-84. Available from: http://www.fcc.org. br/pesquisa/publicacoes/eae/arquivos/1637/1637.pdf

13. Quinquer D. Modelo e enfoques sobre a avaliação: o modelo comunicativo. In: Ballester M, Campos V, Horn MGS, editors. Avaliação como apoio à aprendizagem. Porto Alegre: Artmed; 2003. pp. 1-176.

14. Ramalho AS, Silva FD, Kronemberger TB, Pose RA, Torres MLA, Carmona MJC, et al. Anesthesiology Teaching during Undergraduation through an Academic League: what is the Impact in Students' Learning?. Rev Bras Anestesiol. 2012;62(1):6373. https://doi.org/10.1590/S0034-70942012000100009

15. Stegers-Jager KM, Cohen-Schotanus J, Themmen AP. Motivation, learning strategies, participation and medical school performance. Med Educ. 2012;46(7):678-88. https://doi. org/10.1111/j.1365-2923.2012.04284.x 